\title{
A FEMINIST NEW HISTORICISM READING OF THE PORTRAYAL OF HOT-SPRING GEISHAS IN YASUNARI KAWABATA'S SNOW COUNTRY
}

\author{
Dyah Rochmawati \\ Dosen Prodi Pendidikan Bahasa Inggris - FKIP - Universitas PGRI Adi Buana Surabaya \\ dyra.hadi@yahoo.com
}

\begin{abstract}
Abstrak
Geisha adalah topik yang menarik tentang sejarah dan keindahan wanita Jepang. Geisha sering disalahartikan sebagai prostitusi namun seniman-penghibur (entertainer) tradisional Jepang. Bagaimana kehidupan dan permasalahan yang berhubungan dengan geisha menarik untuk diteliti. Yasunari Kawabata, sastrawan Jepang, menulis cerita tentang geisha dan kisah cintanya dengan lelaki yang dihiburnya dalam novel Snow Country (1947). Beliau pernah memenangkan hadiah Nobel. Artikel ini membahas potret kehidupan geisha dalam novel tersebut dilihar dari sudut pandang feminism dan new historicism.
\end{abstract}

Kata Kunci: Geisha, feminisme dan new historicisme.

\section{Introduction}

The word "geisha" is basically a compound of two words or characters meaning "art" and "person," respectively. The word gei (pronounced gay) means "art" in Japanese. "Geinin" or " geiko" are two other versions of this. However, the most appropriate translation of the word "geisha" is probably "artiste." As for the apprentice geisha, they're referred to as "maiko."

Geisha have long been figures of fascination in Japan and throughout the world. For centuries, they have emerged from their homes at dusk like butterflies from a cocoon for a night's round of teahouse engagements. Social evenings have always been an important part of business in Japan, and the presence of geisha reflects well on the host who can afford such glamorous companions.

Neither wife nor prostitute, a geisha is an artist who earns her living entertaining powerful men. A geisha is a trained dancer, singer and musician, as well as a witty conversationalist. She laughs at her client's jokes - and never tells his secrets. She creates drama with a simple flick of her fan.

Years of hard work and self-discipline have transformed her into this refined creature, but underneath her binding layers of kimono and neutral mask of make-up is a flesh and blood woman with her own history, disappointments and dreams. The secrets she guards most closely belong to her own heart.

The hot-spring geishas are described so vividly in Yasunari Kawabata's Snow Country novel still exist today, and authentic geisha continue to entertain in elegant old teahouses or hot spring inns. They dress, groom themselves and perform as geisha have for centuries. Women who become geisha today are often drawn to the profession through an interest in the traditional arts and may remain in it only a few years. Once their country's most fashionable women, top geisha were the supermodels of their day until "modern" came to be defined as Western in Japan.

Yasunari Kawabata (1899-1972) was a key figure in 20th Century Japanese literature among very few writers from Asia who have managed to penetrate the West literature. He called universal attention to the importance of Japanese literature by receiving Nobel Prize for Literature in 1968. This has made people in the West aware that Japan made valuable contribution to the world of literature. Kawabata brought Japanese literature to the international world of literature. For him, to be the first Japanese Nobel Laureate for Literature would help bridge the West and the 
East. The prize was a symbol of understanding and friendship between East and West (McManus, 1998).

Seidensticker, the translator of Snow Country from Japanese, in Kawabata (1981: x) has stated that the novel is perhaps Kawabata's masterpiece. Snow Country of which the original title is Yukigini was completed in 1947. Snow Country (1947), a stylistic tour de force, analyzes the love and loneliness of a country geisha in a mountain hot-springs resort who has an affair with an urbane dilettante from Tokyo. It is the story of the story of Shimamura, a 'wealthy sophisticate' from Tokyo and Komako, a geisha in a small, nameless village located in the snow country of Japan, which is the snowiest region on Earth. Komako is a girl who became a geisha to help pay the medical bills of a young man who is dying named Yokio. He may or may not be her fiancé. Shimamura is an older, married man with a family. He is described as a dilettante, a wealthy man who lives a life of idleness. Shimamura is a spoiled, somewhat careless man, who spends his time pursuing hobbies rather than a career. Living in two different types of isolation, the two find their love ultimately impossible.

The present paper is going to mainly focus on the portrayal of hot-spring geishas in Kawabata's Snow Country and whether or not those depictions reflect the values of women in Japanese society by using the New Historicism criticism and the Feminist Philosophy as theoretical lenses. It is a method based on the parallel reading of literary and non-literary texts, usually of the same historical period (Barry, 1995: 172). From the perspectives of the New Historicism, literature must be read within the broader context of its culture, in the context of other discourses ranging over politics, religion, and aesthetics, as well as its economic context (Habib, 2005: 760); while the Feminist Philosophy refers to philosophy approached from a feminist perspective.

Specifically, the paper is attempting at answering the following questions:

1. How does the novel address the life of hotspring geishas?
2. What are the causes of becoming a hotspring geisha?

3. Does it resonate with the Japanese people in light of their history?

4. Does the socio-political relevance of Snow Country continue to the present day?

\section{New Historicism}

New Historicist Criticism took shape in the late 1970s and early 1980s as opposed to New Criticism and to the critical deconstruction. It is also new and differ markedly from its former (old) historicism to view literature as a stable events which can be used as "background" of an era, or simply as a "reflection" that refer to material condition (as in early Marxism) of particular epoch of literature. It is a movement considerably inspired by Focault's work and developed by Stephen Greenblatt, Louis Montrose, and others (Hogan, 2000: 158, 166).

Michel Foucault was a French social historian and philosopher of history and best known for his highly influential analysis of power. He addresses a wide range of power relations in a broad range of social structures. In his opinion, power is not merely the strength of state, not merely brute force, but it is a relation in existing in all social structures and it is bound up with thought, study, and systematic theorization (ibid: 179-180).

Hogan (2000: 190) has further stated that every work of literature is firmly bound to its history and culture. New Historicism is therefore a reading of political, legal, literary, and other historical texts through one another, a part of one history or as part of culture, such as its ideological presuppositions, its political implications, its implied manifestations of cultural relations and traditions, its historical relations, to name a few.

Veeser (2007: 3) cited, "Greenblatt, Montrose, and other New Historicists have insistently highlighted the "atrocities" visited on lower class bodies, have lovingly detailed the "colonial torture" lavished on the starkly victimized, "broken, hapless underlings" who people New Historicist prose." The New Historicism involves the parallel study of 
literary text and non-literary texts which make use of some historical data (Barry, 1995: 172).

\section{Feminist Philosophy}

Philosophy is considered to be the 'mother-subject' of all subjects, such as Mathematics, Physics, Economics, and so on. All happened from within philosophy, including the study of Literature. Philosophy deals with some questions known to humanity. Philosophy and Literature share a concern for the great and small truths of human existence. Both can enrich each other. Literature aesthetically assimilates and transmits Philosophy; while philosophical themes contribute to the structural unity of literary works and also to widen the scope of literary theory, such as formalism, new criticism, structuralism, psychoanalysis and so forth (Skilleas, 2001: 1-12). When one is reading a work of literature, what he or she is actually reading is both a work of oratory, an essay, philosophy or scripture and a work of literature (New, 1999: 1).

The forms of social and political philosophy that have been the most prominent in the literary study have tendency to put a great emphasis on how social groups privileges some other groups at the expense of others. One aspect of this study is the analysis of the nature and history of class relations, for instance, relations between sexes, relations between different racial or ethnic groups. The examination covers both the domination itself and the means by which the domination is preserved (Hogan, 2000: 158-159).

Another aspect of the analysis which has perhaps been more central to the study of literature is the analysis of ideology which is the ideas that operate to maintain and extend social hierarchy of class, sex, race, and so forth, outside of repression. They may have a function in sustaining oppressive hierarchies. This is intended to produce political effects: to foster a more profound understanding, critical of capitalism and its racial stratifications, to promote a broader range of aspiration, including aspirations to transform the social structure itself, and so forth (ibid.: 160, 163).
Discourse is not just a way of speaking or writing, but the whole 'mental set' and ideology which encloses the thinking of all members of a given society (Barry, 1995: 176).

One of the most influential American philosophers who have argued that literature to some extent contributes to, and maybe constitutes philosophical inquiry is Martha Craven Nussbaum. She has claimed that some literary works are absolutely necessary to philosophy, or more precisely, moral philosophy. Her view is that in literary narrative life is represented as something in a style which sets up certain reactions in the reader which are suitable for understanding truths about life, knowledge and wisdom about humanity and society. Reading literature, particularly novels, exercises one's perception and abilities to judge people and situations so as to act adequately and to feel the appropriate emotions in given circumstances (Skilleas, 2001: 129-130).

New (1999: 120) has suggested that literature can state or imply various propositions. Works of fiction can sometimes be said to convey moral, political, religious, or any other truths. Sometimes they do set out to covey such supposed truths, and sometimes they succeed.

Thus, literature contributes to expand one's emotional and cognitive capacities. Literature does indeed have the capacity to expand their horizon and to make them understand motivations and world-pictures different from their own through the presentation of its characters in their complete significance equipped with emotional engagement (ibid: 139-140).

Feminism is probably the most important influence on social and political literary in the last half century. The term 'feminism' covers a range of feminism. Despite such differences, most feminists agree that women's basic physical rights to health, nutrition, and so forth, as well as their right to exercise control over their own sexual and reproductive lives have been deprived by men. In the course of human history, most men have 
been deprived those rights often due to race and class, nationality, sexual preference, intellectual capacities, physical disabilities, or less systematic factors, such as personality or appearance (Hogan, 2000: 167-170).

The impact of feminism on literary criticism over the past thirty-five years has been profound and wide-ranging. A host of related disciplines have been affected by feminist literary enquiry, including linguistics, philosophy, history, religious studies, sociology, anthropology, film and media studies, cultural studies, musicology, geography, economics and law (Plain and Sellers, 2007: 15). Goel (2010:403) has further cited:

"Feminist literary criticism is he rebellion of the female consciousness against the male images of female identity and experience. The concept of female identity shows us how female experience is transformed into female consciousness, often in reaction to male paradigms for female experience. It is an ideology that opposes the political, economical and cultural relegation of women to positions of inferiority."

Feminist philosophy is defined as philosophy approached from a feminist perspective. It employs the methods of philosophy to further the cause of the feminist movements and attempts to criticize or reevaluate the ideas of the traditional philosophy from within a feminist framework. The feminist philosophy does not claim to search for knowledge for its own sake, but rather for the sake of a political goal: resistance to, and elimination of, the subordination of women (Gardner, 2006: xxiii).

Lai (2006) has suggested that New Historicism should be reconciled with the mainstream postmodernism, which is more diverse, affirmative and ethico-political than the formalistic and pessimistic theory advocated by Greenblatt. There is the possibility of a feminist new historicism to show how New Historicism can revitalize its critique, cross its limits and thus reach beyond its traditional domain as well.

\section{History of Geisha}

Geisha, or geigi or geiko are traditional, female Japanese entertainers whose skills include performing various Japanese arts, for instance classical music and dance. Geiko is another name for geisha. It is usually used to refer to geisha from western Japan including Kyoto. An apprentice geisha is called maiko. A maiko is paid half of the wage of a full geisha.

A geisha usually put on white and thick make-up and red lipsticks. They also wear elaborate kimono and hair of maiko. These are the most recognizable image held of a geisha. The make-up and kimono they wear features whether they are a maiko or older and mature geisha. The older a geisha, the simpler style she wears to show her own natural beauty.

A woman entering the geisha community does not have to begin as a maiko having the opportunity as a full geisha. A woman above 21 is considered too old to be a maiko and becomes a full geisha upon her initiation into the geisha community. However, those who do go through the maiko stage can enjoy more prestige later in their professional lives.

In the early stages of Japanese history, there were female entertainers called saburuko (serving girls). They were mostly wandering girl whose families were displaced from struggles in the late 600s. Some of these girls sold sexual services; whereas some with a better education made a living by entertaining at high-class social gatherings. After the capital was moved to Kyoto in 794, Japanese Geisha culture began to emerge.

Traditional Japan embraced sexual delights and it is not a Shinto taboo that men could be unfaithful to their wives. The ideal wife was a modest mother and manager of the home. By Confucian custom love had secondary importance. For sexual enjoyment and romantic attachment, men did not go to their wives, but to courtesan. Pleasure quarters were then built in the $16^{\text {th }}$ century. 
Outside of which was considered to be illegal and "play women" called $y$ jo were then classified and licensed. The highest $y$ jo class was the geisha's predecessor, called oiran, a combination of actress and prostitute. They performed erotic dances and skts, and this new art was dubbed kabuki, meaning "to be wild and outrageous". The dances were called kabuki and this was the beginning of kabuki theater.

Near the turn of the $18^{\text {th }}$ century, the first entertainers of the pleasure quarters called geisha, appeared. The very first geishas were men, entertaining customers waiting the most popular and gifted oiran. The forerunners of female geisha were the teenage odoriko (dancing girls) expensively trained as dancersfor-hire. In the 1680 s, they were hired in the private homes of upper-class samurai, though many had turned to prostitution by the early $18^{\text {th }}$ century. The first woman to be known to have called herself geisha was a Fukugawa prostitute, in about 1750. She was a skilled singer and shamisen-player named Kikuya who was an immediate success making female geisha extremily popular in 1750 s Fukugawa.They became more widespread throughout 1760 s and 1770 s, many began working only as entertainer, rather than prostitutes, often in the same establishment as male geisha.

The geisha who worked within the pleasure quarters were essentially imprisoned and strictly forbidden to sell sex in order to protect the business of the oiran. While licensed courtesans existed to meet men's sexual needs, machi geisha served as artists and crudite female companions. By 1800, being a geisha was considered a female occupation, though there are still a few male geisha working today. Eventually, the oiran began to fall out of fashion. By 1830s, the evolving geisha was emulated by fashionable women throughout society. Some women would have sex with male customers, whereas others would entertain strictly with their art forms. Prostitution was legal up to the 1900s, so it was practiced in many quarters throughout Japan.
World War II brought a huge decline in the geisha arts because the majority of women had to work for factories and other places to work for Japan. The geisha name also lost some status during this time prostitutes served American military men. In 1944, everything in the geisha's world including teahouses, bars, and houses was forced to shut down, and all employees were put to work in those factories. About a year later, they were allowed to reopen. The women who returned to the geisha areas decided to reject western influence and revert back to traditional ways of entertainment and life. Compulsory education laws passed in the 1960s made traditional geisha apprenticeships difficult, leading to a decline in women entering the field. The simultaneous growth of Japanese industry, which opened other opportunities for women, further contributed to the decline of geisha industry.

\section{Theory of Prostitution}

Edmund and Korn (2002: 181-187) have cited that prostitution is low-skill, labor intensive, female, and well paid. Prostitution is a multibillion dollar business that employs millions of women worldwide. Prostitution is the "act or practice of engaging in sexual intercourse for money." But a prostitute cannot simply be a woman who sells her body since "that is done every day by women who become wives in order to gain a home and a livelihood" Prostitution has an unusual feature: it is well paid despite being low-skill, labor intensive, and, one might add, female dominated. Earnings even in the worst-paid type, streetwalking, may be several multiples of full-time earnings in professions with comparable skill requirements. Most people would agree that sleeping around does not amount to prostitution.

Prostitution has a poor reputation. Once a woman is identified as a prostitute, her ability to marry is reduced. Humans not only mate but also marry. Men prefer their wives to be faithful (for instance, from a desire to raise biological children); whereas Women rarely pay men for commercial sex, possibly for the 
same reason that women sell to men Hence, prostitution and marriage are largely incompatible for women. Empirically, unmarried women are overrepresented among prostitutes. Although some prostitutes marry, it is a fair guess that, on average, they do so on less favorable terms than they would have done otherwise. Also, some women prostitute themselves while married. However, in many cases these women are separated from their husbands or their marriage may have ceased to exist in anything but form.

Married men are underrepresented among clients; they nonetheless constitute the bulk of demand married men also consult prostitutes. This begs the question why married men go to prostitutes (rather than buying from their wives, who presumably would be low-cost providers considering that they can sell nonreproductive sex without compromising their marriage).

Prostitution has been associated with poverty. Low potential for female labor market earnings is often taken to be an important reason why women go into prostitution, and in any society a higher proportion of poor women prostitute themselves. Slavery is a more common feature of prostitution than other lowskilled professions. In times and places in which forced labor has been used, prostitution was no exception. Examples include slaves in Roman and Greek antiquity and the so-called comfort women held by the Japanese army during World War II.

Prostitution has been organized according to similar principles across different times and cultures. At the bottom we find street prostitution, followed by brothels, bars, and clubs. Call girls and escort agencies occupy the middle to high slots and kept women the top rungs. Higher-end prostitutes are better looking, younger, and healthier; charge more per client; and spend more time with each. Typically, both earnings and working conditions are better more up market: clients are fewer, venues more agreeable, and client screening more selective. Received wisdom has it that prostitutes are trapped in either economic or emotional bondage or work under slave-like conditions; though other studies paint a similar picture of prostitution as well paid.

\section{Research Method}

Dealing with the achievement of an intended goal in answering the research problems, the present study employed a descriptive qualitative research method. The word qualitative implies an emphasis on processes and meanings that are not rigorously examined or measured in terms of quantity, amount, intensity, or frequency. Qualitative research involves an interpretive, naturalistic approach to its subject matter. It is applied to investigate things in their natural settings, attempting to make sense of, or interpret phenomena in terms of the meanings people bring to them. It involves the studied use and collection of a variety of empirical materials, such as case study, personal experience, introspective, life story, interviews, observational, historical, interactional, and visual texts (Denzin and Lincoln, 1994: 2).

This research used library research through documentation techniques to collect the data, because the data of this research were written documents. The data employed in the present study were the sentences and utterances which are composed in dialogue and description, for example about characters, setting of time, setting of places, etc, in Yasunari Kawabata's novel Snow Country (1947). Meanwhile, the supporting data are additional data which have close relationship with the source of data. In this research, the supporting data are taken from the other sources; related journals of literature, e-books, and internet references.

In addition, the collecting data method includes several steps, as follows; intensive close reading, noting the data, highlighting, extracting data from the novels are chosen in doing this research from the beginning up to producing the result of this research. The data analysis in this qualitative research employs some flows of activities: data reduction, data 
display, and conclusion drawing (Miles and Huberman, 1994: 12).

\section{Analysis and Discussion}

\section{A. The Figure of Hot-Spring Geishas in Kawabata's Snow Country}

As previously mentioned, Kawabata's Snow Country portrays vividly the life of a hot-spring geisha through Komako, one of its main characters. The following section presents the hot-spring geisha figure in Kawabata's Snow Country through a New Historicism reading:

\section{The Appearance of a Hot-Spring Geisha}

A geisha's appearance changes through her career from the girlish and heavily-made maiko to the more somber appearance of an older established geisha. Different kimono, hairstyles, hairpins, and even the length of eyebrows signify different stages of a young girl's development or maturity. The whole idea is perfection. They cannot charge guests to look at imperfection.

A geisha always wear kimono. An apprentice geisha wears highly colorful kimono with extravagant obi. Obi is the sash worn over the kimono, women's are usually wider than that worn by men. It is considered to be an important fashion accessory. The obi is always brighter than the kimono she is wearing to give a certain exotic balance. In addition to the heavy dangling obi, pocketed sleeves called furi is wrapped to avoid tripping.

The color, pattern, and style of kimono is dependent on the season and the event the geisha is attending. In winter, a geisha can be seen wearing a three-quarter length haori lined with hand-painted silk over their kimono. Lined kimonos are worn during colder seasons, and unlined kimonos during the summer.

Snow country portrays the appearance of a hot-spring geisha through Komako.

"There was something the woman gave was a wonderfully clean and fresh
one...There was something about her manner of dress that suggested the geisha, but she did not have the trailing geisha skirts,... she wore her soft, unlined summer kimono." (18)

This shows that the way a hot spring geisha wears is different from other geishas in other regions. The time setting of the story was the cold winter season. In the season a geisha usually wears lined kimonos. However, Komako did not wear lined, but unlined summer kimono. They way she was wearing signified that she was a geisha. She also wore an expensive obi, though it did not suit her kimono. Shimamura caught a glimpse of sadness in the dress she was wearing. She also had the short, thick eyebrows sloping gently down to enfold the line discreetly. Besides, the line of her eyelids neither rose nor fell (32).

Yoko, who sometimes served as an "apprentice" geisha, wore even inexpensive kimono, unlike other maikos in other regions who had more exotic appearance. She was wearing "mountain trousers" and an orangered flannel kimono (109). Having looked at the appearances of both of Komako and Yoko, Shimamura who came from Tokyo considered them as "ordinary amateurs" (17) and they could hardly be as good as all that (71).

Thus the hot spring geisha's appearance is different from other geishas' in other cities, such as Tokyo and Kyoto. The impression she gave was all one of cleanness, not quite one of real beauty (32). It indicates that the hot-spring geishas belong to the lower class geishas. Even though the hot-spring geishas are trained to be skilled geishas, it seems that they are less professional that other geishas are.

\section{The Motives of Being a Hot-Spring Geisha}

There is a close link between poverty and prostitution (Edlund and Korn, 2002: 181). This means that those who become prostitutes mostly have economic motives. They chose to be prostitutes to earn their living.

In the geisha society, a maiko is bonded under a contract to her okiya. The okiya supplies her with food, board, kimono, obis 
and other tools of her trade. Her training is very expensive and her debts must be repaid to the okiya with the earning she makes. This repayment may continue after the maiko becomes a full-pledged geisha, and only when her debts are settled is she permitted to move out to live and work independently.

The similar thing happened to Komako. In the novel, Komako, who was born in that snow country, but she had been put under contract as a geisha in Tokyo as she found a patron who paid her debts for her and proposed to set her up as a dancing teacher. Unfortunately, she died a year and a half later (18-19). Since her son, Yukio, was suffering from intestinal tuberculosis, she became a geisha to help pay his doctor's bill $(55,60)$.

Yukio had as a matter of fact not been born in the snow country. It was his mother's home. His mother had taught dancing down on the coast even when she was no longer a geisha, but she had had a stroke while she was still in her forties, and had come back to this hot spring to recover (55).

His mother once thought that it would be a good idea for Yukio and Komako to get married. But she only thought it and never said a word. They were in fact never engaged. Komako said that it was not to help anyone that she became a geisha, but she did it because she owed a great deal to his mother and was urged to do what she could (67).

\section{Hot-Spring Geisha vs. City Geisha}

There is a complex geisha ranking system. The five geisha districts known as hanamachi meaning "flower towns" in Kyoto are in the highest ranks. At the opposite end of the sytem are hot-spring geisha. These geishas work in spa resorts and are viewed by most Japanese as no better than common prostitute. They normally cater to far less exclusive patrons, and are much less expensive.

"If the hot-spring geisha is not a social outcast, she is perilously near being one. The city geisha may become a celebrated musician or dancer, a political intriguer, even a dispenser of patronage." (vi)
Besides, the hot-spring geisha must go on entertaining week-end guests, and the pretense that she is an artist and not a prostitute is often a thin one indeed. She may marry a old guest or persuade him to open a restaurant for her.

Like all geishas, they are trained in the art of Japanese dance and music. There are the three elements of the training. The first is the formal arts training which takes place in special geisha schools. The second element is the entertainment training at teahouses and parties. The third is the social skills to build the social network needed to survive as a geisha and it is done on the streets.

The geishas begin their study of music and dance when they are very young and continue it throughout their lives. The dance of the geisha has evolved from the dance performed on the kabuki stage. The dances are accompanied by the traditional Japanese music in which the primary instrument is the shamisen. This shamisen, originating from Okinawa, is a banjo-like three-stringed instrument played with a plectrum and often accompanied by flute. It has a melancholy sound. Some geisha would not only dance and play music, but would write beautiful, melancholy poems. Other painted pictures or composed music.

This can indeed be found in the novel. Komako, as a hot-spring or mountain geisha, entertained the guests in the hot-spring inn. Many guests came during the skiing season (14). When the winter was over, the season for climbing mountains in the spring green came (16). It would keep Komako and other mountain geishas busy (17).

In a mountain village, the arrangements between a geisha and her keeper were so easygoing (27). However, it was up to the geisha whether she would stay the night or not. If she stayed without permission from her house, it was her own responsibility. If she has permission the house took full responsibility, notably if there should happen to be a child or some sort of disease.

The house that kept geishas would generally have a faded shop curtain that advertised it as a restaurant or a tearoom. The 
shop that sold candy, tobacco or groceries might have its one geisha. Its owner would have his small farm besides the shop and the geisha (27).

\section{The Personal Relationship with Male Guests}

It is true that a geisha is free to pursue personal relationships with men she meets through her work. Geishas are expected to be single women and those who choose to marry must retire from the profession. It was also traditional in the past for established geisha to take a patron or danna. A danna was typically a wealthy man, sometimes married. This sometimes occurs today as well, but very rarely. A geisha and her danna may or may not be in love, but intimacy is never viewed as a reward for the danna's financial support. The traditional conventions and values within such a relationship are very intricate and not well understood, even by many Japanese.

That kind of love affair may also happen to a hot-spring geisha as that is a hot spring and people are here for a day or two and gone. The relationship of Komako, a hot-spring geisha, and Shimamura, who was once the guest she entertained, was portrayed in the novel. It was an uncertain relationship as Shimamura is a married man with some children.

"An affair of the moment, no more. Nothing beautiful about it. You know that-it couldn't last." (22)

For Shimamura, as that was his first taste of the snow country winter, Komako was someone who met his need for a companion. He came to the hot spring trying to decide where he would go to escape the summer heat. It was therefore friendship more than anything else that he felt for the woman (19).

Unfortunately, Komako did not feel the same way. She was deeply in love with him. Having met Shimamura, who came from Tokyo, she thought that she would have a chance to go to the city as she had been longing for the city (43).
"There was something lonely, something in it, something that rather

suggested a beggar who has lost all desire." (42)

Their relationship seemed on edge as Shimamura was also attracted to Yoko, who was taking care of Yokio, the music teacher's son. He was very ill and Yoko took a good care of him for Komako. Shimamura's heart was bouncing between Komako and Yoko. It was definitely a wasted effort.

"Shimamura felt, he woud drawn into a remote emotionalism that would make his own life a waste..." (43)

Thus, the relationship which a hot-spring geisha, and any other geisha, may have with their male guests tends to be an uncertain and loose relationship. Any effort to make it happen to a life-long commitment, such as a sacred marriage, will be surely wasted. Those who choose to marry must retire from the profession.

\section{Hot-Spring Geisha and Prostitution}

There remains some confusion about the nature of the geisha profession. Geisha are regarded as prostitutes by many non-Japanese people and Japanese themselves. However, legitimate geisha do not engage in paid sex with clients. Their purpose is to entertain their customer by dancing, reciting verse, playing musical instruments, or engaging in light conversation. Geisha engagements may include flirting with men and playful innuedos, however, clients know that nothing more can be expected. It is up to the guest, after all, when he wants to let geisha go (31).

The similar thing happens in the novel as Shimamura realized what would happen to Komako and him.

"In any case, he had revised his view of her, and he found, surprisingly, that her being a geisha made him even more difficult for him to be free and open with him." (43)

Prostitution was legal in Japan until 1958, which is another reason that people may be misinformed about geishas not offering sex to customers. Moreover, many of the 
professional prostitutes who catered to the occupying soldiers after World War II styled themselves as "geisha". Modern geisha still live in traditional geisha houses. Many experienced geishas are successful enough to choose to live independently, even though. A geisha might have lived in a variety of circumstances ranging from complete independence to a state of virtual captivity.

However, the patronage of a courtesan was considered natural, necessary, and not unfaithful. Extramarital affairs on the part of the husband were the norm, but of course, women were not afforded this luxury. Wives were, in a way, more caged than the geishas were (Thayer, 2008: 17). Many times a patron or danna was a married lover, who also had the means to support her. He pays off any debts she might have with her sponsoring house or okiya and makes a commitment to support her financially, including provision for an apartment or house. In exchange for this support, a geisha becomes essentially a mistress, staying with her danna when he wishes, accompanying him on trips, and perhaps even bearing his children. He would pay for her kimono, rent, hairdresser appointments, and her music and dance lessons. Even today, if a geisha's danna requests her presence at a party, she cancels all of her conflicting engagements and attends to him.

The hot-spring geisha portrayed in the novel exist as a spirit and as a personality, and very little to least possible as a body and we have nothing erotic in the novel even in a sexual scene.

\section{Hot-Spring Geisha and Matriarchal Society}

The geisha culture is the only business in Japan that is run exclusively by women for the pleasure of men and has been successful for many centuries. In this society, where a woman's place was either in the home or in the brothel, the geisha carved out a separate niche, creating a community of women that became known as the karyuaki (flower and willow world). Despite the often harsh realities of this world, a geisha could gain an education of sorts, acquire an art, make her own money, establish an independent identity, run a business, pursue romance, and sometimes find true love.

Women in the geisha society are some of the most successful businesswomen in Japan. In the geisha society, women dominate and run everything, whereas men have a limited role. The geisha system was founded, in fact, to promote the independence and economic selfsufficiency of women. Becoming a geisha was a way for women to support themselves without submitting to becoming a wife.

The women depicted in the novel were similar to the female-dominance society previously mentioned. Komako, for instance, she supported herself by being a geisha. Next, the music teacher or Komako's patron was once a geisha. When she was retired, she became a music and dancing teacher. Yoko made a living by taking a care of Yokio.

"I take care of myself. Think of all the money I could make if I really tried...I know about how much it takes each month for an installment on the loan, and interest, and taxes, and my own keep...”(107)

Aside from the actual entertainment of the client-typically involving flirting, sake drinking, and music-many geisha were indentured to their okiya, the "teahouses" in which they lived, and like the courtesans, constantly accrued debts for their kimono, makeup, room and board, etc.

Moreover, in this female-dominance society there is the separation of female realms in a husband's life. Wives and the women of the "floating world" are two sides of the same coin. On the one hand, a husband requires one woman to produce and raise an heir, manage the household, and dutifully respect him, but for love, he has to go to the courtesan and the geisha (Thayer, 2008: 18).

\section{Geisha in Today's Japanese Society}

For many years the world of the geisha, 
often referred to as the flower and willow world, has perplexed and intrigued people around the world. The most common image of a geisha is a white faced, red lipped, kimono clad, glorified prostitute.

Despite the criticisms of the West, the socalled "flower and willow world" became and remains the heart of Japanese cultural tradition. Japan and the world currently view the geisha as the retainers of "Japaneseness." Instead of actually being repositories of tradition, they are the maintainers of it (Thayer, 2008: 6).

The ways that prostitution developed in Japan, however, provide an interesting comparison with how people outside Japan view prostitution. They have denied their existence and reality and projecting a form of socially acceptable sexual repression onto them. Throughout Japan's history, however, Japan has been exceptional for its frank acknowledgement of the existence of prostitution in all forms (ibid: 7).

The Japanese government, instead of focusing on the pleasure quarters as a source of negative social influence, recognized them as legitimate areas of relaxation and release from humdrum everyday life. The government, however, believed that these pursuits of pleasure were characteristics of only the middle class. In order to keep this class from getting beyond its control and to remind its subjects that it controlled every aspect of their lives, the emperor's-and eventually the shogun's-government restricted prostitution to walled-in areas on the outskirts of major cities. The most famous and decadent of these government-licensed prostitution districts was the Yoshiwara in Edo-modern day Tokyo. This district was moved outside of Edo's city walls in 1656, and afterwards became the flagship red-light district of the nation. Within the walls of the district, prostitution developed its own society, influencing and shaping the world outside. The women contained in these districts ran the gamut in class and served a clientele who could vary greatly in social status. (ibid: 11)
The prostitutes and courtesans within the Yoshiwara represented a dichotomous existence: social outcasts on the one hand yet countenanced by society on the other, and as the posterity of the noble court tradition, the courtesans were the retainers of a time of poetry, beauty, and ritual. By the Edo period, the public was looking to courtesans in the Yoshiwara for entertainment, culture, and fashion.

In the Yoshiwara, wives and the home they maintained were irrelevant and symbolized the opposite of everything that the pleasure districts sought to provide. Gesihawere the complementary opposite of the wives of the men who patronized them. They played the two roles as "complementarity without antagonism" and a "feminine division of labor" (ibid: 16).

In Japan, courtesans provided sexual fantasy and also sexual favors when they chose to do so, while the geisha took the role of entertainer. But the division was never totally clear-cut. Outside of the urban pleasure quarters, in towns that were not large enough for walled-in "floating worlds" in which courtesans' business could be threatened, geisha who also functioned as prostitutes were required to have licenses for both prostitution and entertainment. Courtesans, for the majority of their existence, were popular and beautiful enough to choose their own customers. Once the geisha eclipsed them in popularity, however, many courtesans who were desperate for money accepted many more clients than they would have only fifty years prior. Because the geisha established herself from the start as a complement to courtesans' services and not an alternative, however, she was always a free woman who could choose her own lover. Coincidentally, the geisha's sexual freedom made her even more appealing to men (ibid: 23).

The heart of the geisha life lay in two Japanese cities, Kyoto and Tokyo. One, Kyoto, is a snapshot in time of the geisha of the past; living in the hanamachi with their geisha family, learning the arts, and preserving the 
way of the geisha. The other, Tokyo, is struggling to retain the dwindling geisha arts where technology advancement threatens to take over.

The hot-spring geisha and her world as vividly depicted in the novel continue to fascinate people around the world as part of their image of a mysterious and timeless Japan. Prostitution is of course referred to as the "oldest profession," and the history of the geisha stretches back several centuries. But while many people assume that geisha is just a Japanese word for a prostitute, the somewhat more romantic word 'courtesan' is probably closer in nuance, though even that is misleading when their history is considered. The word geisha itself literally means 'person of the arts' - indeed the earliest geisha were men - and it is as performers of dance, music and poetry that they actually spend most of their working time.

\section{Conclusion}

In conclusion, the geisha figure is an important part of Japanese civilization and tradition. The geisha tradition has been alternately glorified by the Japanese society and outlawed by the Japanese law as a form of prostitution due to the evolving duality of the geisha as both artisan and courtesan. Also, the geisha tradition involves force, fraud, and deception.

The geisha have come to symbolize those very traditions that are now regarded as integral to Japanese cultural heritage. The geisha's existence, by extension, reflects and demonstrates the status of Japanese culture.

Yasunari Kawabata's 1947 novel Snow Country revived interest in an aspect of Japan that is so intrinsic to the Western stereotype and yet so far removed from the reality of daily life here. This is what is being represented by Komako in the novel. It is not by chance that Yasunari Kawabata has chosen a hot-spring geisha for the heroine and the dark snow country for the setting of this novel. Geisha do still exist and ply their trade, of course. But the role they play in modern society is minor and, except for the attention they get from camera-wielding tourists, largely unseen.

\section{References}

Barry, Peter. 1995. Beginning Theory. Machester, U.K.: UP

Edmund, Lena and Korn, Evelyn. 2002. A Theory of Prostitution. In Journal of Political Economy. Vol. 110, no. 1. The University of Chicago.

Gardner, Catherine Villaneuva. 2006. Historical Dictionary of Feminist Philosophy. Maryland: Scarecrow Press, Inc.

Habib, M.A.R. 2005. A History of Literary Criticism from the Plato to the Present. M.A., Oxford, Victoria: Blackwell Publishing Ltd.

Kawabata, Yasunari. 1981. Snow Country (Translated by Edward G. Seidensticker). New York: G.P. Putnam's Sons (Perigee Books)

Lai, Chung-Hsiung. 2006. Limits and Beyond: Greenblatt, New Historicism, and a Feminist Genealogy. In Intergrams, 7.1-7.2. Retrieved from http://benz.nchu.edu.tw/ intergrams/ 071-072/071-072-lai.pdf on 28

January 2012.

McManus, Barbara F. 1998. Reader-Response Criticism. Retrieved from (www.geocities.com/SunsetStrip/A lley/7564/snowcountry.html).on 10 October 2011, at 11: 39 p.m.

New, Christopher. 1999. Philosophy of Literature: An Introduction. London and New York: Routledge.

Skilleas, Ole Martin. 2001. Philosophy and Literature: An Introduction. 
Edinburg: Edinburg University Press,Ltd.

Thayer, David Sumner. 2008. The Development of Geisha and Their Present Status as Symbol of Japanese Culture, Tradition, and Feminity. Unpublished Thesis. Boston: Boston University Academy.

Veeser, Aram, H. 2007. Re-Membering a Deformed Past: (New) New Historicism. In The Journal of the Midwest Modern Language Association, Vol. 24, No. 1, Cultural Studies and New Historicism. (Spring, 1991), pp. 313. Retrieved from http://www.jstor.org Mon Jul 2 16:52:40 2007 
